Jurnal Perikanan Pantura (JPP) Volume 1, Nomor 1, Maret 2018

\title{
PENGARUH PENAMBAHAN SERBUK DAUN KAYU MANIS (Cinnamomum burmanii) PADA PAKAN TERHADAP KELANGSUNGAN HIDUP DAN PERTUMBUHAN IKAN NILA (Oreochromis niloticus)
}

\author{
Moh. Fikri Ubaidillah ${ }^{1}$, Farikhah ${ }^{2}$, Firma Fika Rahmawati ${ }^{2}$ \\ ${ }^{1}$ Mahasiswa prodi Budidaya Perikanan, Fakultas Pertanian, Universitas Muhammadiyah Gresik \\ ${ }^{2}$ Dosen Prodi Budidaya Perikanan, Fakultas Pertanian, Universitas Muhammadiyah Gresik \\ Email : fikri040495@gmail.com, Phone+6281358195947
}

\begin{abstract}
The use of phytopharmaca is not well known to all tilapia farmers, especially in Gresik Regency which is partly cultivation of Oreochromis niloticus tilapia fish.Demand for tilapia in the market is quite high as the number of restaurants that make tilapia as one of the menu.Cinnamomum burmanii, cinnamon leaf powder is dried and crushed and easy enough to make it effectively cheaper than chemicals that are expensive enough to improve the survival and growth of tilapia.This study aims to determine the best dosage of the addition of Cinnamomum burmanii, cinnamon leaf powder.The method used was complete random design (CRD) with treatment of dose of cinnamon leaf dose (control), $0.25 \%, 0.5 \%, 1 \% / \mathrm{kg}$ of feed per treatment consisted of 3 replications.Parameters observed for survival, absolute weight and daily growth rate. The results of this study showed that the best dosage of cinnamon leaf powder had a significant effect on survival, absolute weight and daily growth rate of tilapia. The best dosage is the addition of cinnamon leaf powder for survival, absolute weight and daily growth rate at a dose of $0.25 \% / \mathrm{kg}$ of feed.
\end{abstract}

Keywords:Tilapia (Oreochromis niloticus), Cinnamon Leaf Powder, Survival Rate, Absolute Growth, Spesific Growth Rate.

\section{PENDAHULUAN}

\subsection{Latar Belakang}

Pada umumnya ikan nila (Oreochromis niloticus) merupakan ikan air tawar yang sering dibudidayakan oleh petani tambak yang ada di Indonesia. Peningkatan budidaya ikan nila tidak lepas dari keunggulan komparatif biologis sebagai ikan omnivore yang memiliki toleransi yang luas terhadap lingkungan dan aspek ekonomis peraktis yang dimiliki seperti cara budidaya yang mudah, rasa daging yang digemari, dan harga relative terjangkau (Suriawidjaja, 2005; Wardoyo Tsadik, 2007). Ikan ini telah di budidayakan disebagaian besar wilayah propinsi di Indonesia. Produk ikan nilai pada tahun 1996 tercatat sebesar 25.668 ton dan meningkat menjadi 148.249 ton pada tahun 2005. Dengan demikian telah terjadi peningkatan sebesar $578 \%$ dalam kurun waktu 9 tahun (Anonim, 2006)

Bagian dari pohon kayu manis yang sering digunakan atau dimanfaatkan adalah kulit batang dan daun yang dapat diolah menjadi mnyak atsiri. Kulit kayu manis memiliki zat aktif seperti flavanoid, saponin, tannin dan alkanoid (Azim et al. 2004). Kandungan dari komponen kimia kayu manis akan semakin meningkat dengan meningkatnya umur pohon kayu manis, meskipun kandungan komponen kimia tersebut belum atau tidak merubah komposisi kandungan kimianya (Hamidah et al. 2009). Pada ikan patin berukuran 7,36 $\pm 0,27$ g penambahan tepung daun kayu manis pada pakan dapat meningkatkan protein tubuh, retensi protein, dan kecernaan protein (Setiawati et al. 2014). 
Jurnal Perikanan Pantura (JPP) Volume 1, Nomor 1, Maret 2018

\section{Studi Literasi}

Ikan nila (Oreochromis niloticus) merupakan ikan air tawar yang termasuk dalam family Cichlidae dan merupakan ikan asal Afrika. Ikan ini merupakan jenis ikan yang diintroduksi dari luar negeri, ikan tersebut berasal dari Afrika bagian Timur di sungai Nil, danau Tangayika, dan Kenya lalu dibawa ke Eropa, Amerika, Negara Timur Tengah dan Asia. Di Indonesia benih ikan nila resmi didatangkan dari Taiwan oleh Balai Penelitian Perikanan Air Tawar pada tahun 1969. Ikan ini merupakan spesies ikan yang berukuran besar antara 200-400 gram sifat omnivora sehingga bisa mengkonsumsi makanan berupa hewan dan tumbuhan (Amri dan Khairuman, 2003).

Cinnamomum burmanii merupakan tanaman rempah dari famili Lauraceae yang terdiri dari beberapa spesies (Rismunandar dan Paimin, 2001). Di pasaran kayu manis dikenal dengan sebutan casiavera atau cinamon (Nazaruddin, 1993). Menurut Rismunandar dan Paimin (2001) ada beberapa faktor yang mempengaruhi pertumbuhan, perkembangan, dan kualitas kayu manis. Faktor-faktor tersebut adalah ketinggian tempat, curah hujan, kondisi tanah, topografi, dan air tanah. Kayu manis dapat tumbuh hingga ketinggian $2000 \mathrm{~m}$ dari permukaan laut, membutuhkan iklim tropis basah dengan curah hujan 2000-2500mm/tahun. Kandungan kimianya antara lain minyak atsiri, safrole, sinamadehid, eugenol, tanin, damar, kalsiumoksanat, dan zat penyamak. Sinamaldehid merupakan turunan dari senyawa fenol. Menurut Moestafa (1988) dan Chairul (1994) minyak atsiri dari Cinnamomum burmanni memiliki komponen utama sinamaldehida dan dehidrokarveol asetat sedangkan menurut Gunawan dan Mulyani (2004).

\section{METODE PENELITIAN}

\section{Perlakuan dan rancangan percobaan}

Penelitian dilakukan menggunakan metode eksperimen menggunakan rancangan acak lengkap (RAL) dengan empat perlakuan dan tiga kali ulangan. Perlakuan yang diberikan adalah dengan pemberian pakan yang telah dicampur dengan penambahan daun kayu manis (Cinnamomum burmanii) disajikan pada Tabel 1.

Tabel 1. Perlakuan pemberian pakan dengan penambahan serbuk daun kayu manis (Cinnamomum burmanii)

\begin{tabular}{ll}
\hline Perlakuan & Keterangan \\
\hline K- & Pemberian pakan komersil serta putih telur sebagai binder $2 \% / \mathrm{kg}$ pakan \\
A & Pemberian pakan dan penambahan dosis $0,25 \% / \mathrm{kg}$ pakan serbuk daun \\
& kayu manis serta putih telur sebagai binder $2 \% / \mathrm{kg}$ pakan \\
B & Pemberian pakan dan penambahan dosis $0,5 \% / \mathrm{kg}$ pakan serbuk daun \\
& kayu manis serta putih telur sebagai binder $2 \% / \mathrm{kg}$ pakan \\
C & Pemberian pakan dan penambahan dosis $1 \% / \mathrm{kg}$ pakan serbuk daun kayu \\
& manis serta putih telur sebagai binder $2 \% / \mathrm{kg}$ pakan \\
\hline
\end{tabular}

\section{Parameter Penelitian}

Bobot Mutlak

Rumus perhitungan menurut (Zonneveld et al, 1991):

$$
\mathrm{PM}=\mathrm{Wt}-\mathrm{Wo}
$$

Keterangan :

PM :Pertumbuhan Mutlak (g)

Wt : Berat Akhir (gram)

Wo : Berat Awal (gram) 


\section{Laju Pertumbuhan Spesifik}

Laju pertumbuhan spesifik/ Spesific Growth Rate (SGR) dapat diketahui dengan melakukan perhitungan dengan rumus (Asmawi, 1983)

$$
\text { (Ln Wt - Ln Wo) }
$$

$\mathrm{SGR}=\frac{(\mathrm{t}}{\mathrm{t}} \times 100 \%$

Keterangan :

SGR = Laju Pertumbuhan spesifik

$\mathrm{Wo}=$ Berat ikan pada hari ke-0 $(\mathrm{g})$

$\mathrm{Wt}==$ Berat ikan pada hari ke-t $(\mathrm{g})$

$\mathrm{t}=$ Lama waktu pemeliharaan (hari)

Kelangsungan Hidup Survival Rate (\%)

Rumus perhitungan kelangsungan hidup menurut Nuryati et $l$. (2010) yaitu:

Keterangan :

$$
\mathrm{SR}=\frac{\mathrm{Nt}}{\mathrm{No}} \times 100 \%
$$

SR : Kelangsungan hidup (\%)

$\mathrm{Nt} \quad$ : Jumlah ikan yang hidup pada akhir pengamatan(ekor)

No : Jumlah ikan yang hidup pada awal uji tantang(ekor)

\section{Analisis Data}

Data yang diperoleh dianalisis dengan menggunakan ANOVA (Analysis of Variance) dengan selang kepercayaan 95\%, jika berpengaruh nyata $(\mathrm{p}<0,05)$ maka dilanjutkan dengan uji Tukey dengan selang kepercayaan 95\%, untuk melihat perbedaan antara perlakuan pada penelitian ini $(\mathrm{p}<0,05)$.

\section{HASIL DAN PEMBAHASAN}

\section{Kelangsungan Hidup Survival Rate (\%)}

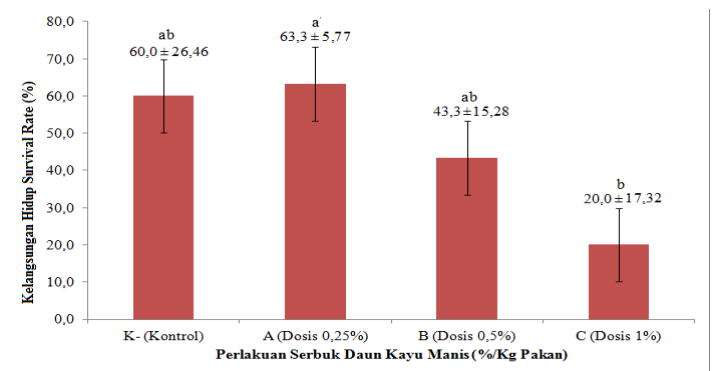

Gambar1. Kelangsungan Hidup Survival Rate (\%) Ikan Nila (Oreochromis niloticus) selama penelitian.

Tabel 3. Analysis of variance (ANOVA)Data Kelangsungan Hidup Survival Rate (\%)Ikan Nila (Oreochromis niloticus) yang di beri pakan serbuk daun kayu manis selama 30 hari pemeliharaan.

\begin{tabular}{llllll}
\hline SK & Db & JK & KT & F hitung & F5\% \\
\hline Perlakuan & 3 & 3775,583 & 1258,528 & 4,663 & 0,036 \\
Galat & 8 & 2159,333 & 269,917 & & \\
Total & 11 & 5934,917 & & & \\
\hline
\end{tabular}

Hasil uji ANOVA pada kelangsungan hidup survival rate (\%) ikan nila (Oreochromis niloticus) menunjukkan bahwa perlakuan dengan pemberian dosis serbuk daun kayu manis 
Jurnal Perikanan Pantura (JPP) Volume 1, Nomor 1, Maret 2018

(Cinnamomum burmanii) yang berbeda pada pakan berpengaruh nyata terhadap parameter yang diamati $(\mathrm{p}<0,05)$.

Tabel 4. Uji Tukey Kelangsungan Hidup Survival Rate (\%) Nila (Oreochromis niloticus) yang di beri pakan serbuk daun kayu manis selama 30 hari pemeliharaan.

\begin{tabular}{|c|c|c|c|c|}
\hline Perlakuan & Perlakuan & $\begin{array}{l}\text { Rata-rata } \\
\text { perbedaan }\end{array}$ & Std. Error & Signifikan \\
\hline \multirow[t]{3}{*}{$\begin{array}{l}\text { PerlakuanK- } \\
\text { (Kontrol) }\end{array}$} & $\begin{array}{l}\text { A } \\
0,25 \% / \mathrm{kg} \text { pakan }\end{array}$ & $-16,66667$ & 13,41434 & 0,620 \\
\hline & $\begin{array}{l}\mathrm{B} \text { dosis } 0,5 \% / \mathrm{kg} \\
\text { pakan }\end{array}$ & 10,00000 & 13,41434 & 0,876 \\
\hline & $\begin{array}{l}\mathrm{C} \text { dosis } 0,1 \% / \mathrm{kg} \\
\text { pakan }\end{array}$ & 32,33333 & 13,41434 & 0,152 \\
\hline \multirow{3}{*}{$\begin{array}{l}\text { Perlakuan A } \\
\text { dosis } 0,25 \% / \mathrm{kg} \\
\text { pakan }\end{array}$} & K- (Kontrol) & 16,66667 & 13,41434 & 0,620 \\
\hline & $\begin{array}{l}\mathrm{B} \text { dosis } 0,5 \% / \mathrm{kg} \\
\text { pakan }\end{array}$ & 26,66667 & 13,41434 & 0,268 \\
\hline & $\begin{array}{l}\mathrm{C} \text { dosis } 0,1 \% / \mathrm{kg} \\
\text { pakan }\end{array}$ & $49,00000^{*}$ & 13,41434 & 0,027 \\
\hline \multirow{3}{*}{$\begin{array}{l}\text { Perlakuan } \quad \text { B } \\
\text { dosis } \quad 0,5 \% / \mathrm{kg} \\
\text { pakan }\end{array}$} & K- (Kontrol) & $-10,00000$ & 13,41434 & 0,876 \\
\hline & $\begin{array}{l}\text { A dosis } \\
0,25 \% / \mathrm{kg} \text { pakan }\end{array}$ & $-26,66667$ & 13,41434 & 0,268 \\
\hline & $\begin{array}{l}\mathrm{C} \text { dosis } 0,1 \% / \mathrm{kg} \\
\text { pakan }\end{array}$ & 22,33333 & 13,41434 & 0,399 \\
\hline \multirow{3}{*}{$\begin{array}{ll}\text { Perlakuan } & \mathrm{C} \\
\text { dosis } & 0,1 \% / \mathrm{kg} \\
\text { pakan }\end{array}$} & K- (Kontrol) & $-32,33333$ & 13,41434 & 0,152 \\
\hline & $\begin{array}{l}\text { A } \quad \text { dosis } \\
0,25 \% / \mathrm{kg} \text { pakan }\end{array}$ & $-4900000 *$ & 13,41434 & 0,027 \\
\hline & $\begin{array}{l}\mathrm{B} \text { dosis } 0,5 \% / \mathrm{kg} \\
\text { pakan }\end{array}$ & $-22,33333$ & 13,41434 & 0,399 \\
\hline
\end{tabular}

*Perbedaan yang signifikan dengan tingkat kepercayaan $95 \%$ atau $(\mathrm{p}<0,05)$.

Semakin tinggi dosis serbuk daun kayu manis pada penelitian ini menyebabkan daya hidup ikan nila (Oreochromis niloticus) semakin menurun hal ini disebabkan karena kandungan serbuk daun kayu manis berupa tanin dan saponin yang memiliki fungsi sebagai anti bakteri dan yang dapat meningkatkan sistem imun, tetapi dengan semakin tinggi dosis serbuk daun kayu manis makan akan memunculkan zat racun yang dapat menghambat proses metabolisme pada tubuh ikan sehingga dapat menyebabkan kematian. Tanin merupakan senyawa aktif metabolit yang diketahui mempunyai beberapa khasiat diantaranya sebagai astringen, antidiare, antibakteri dan antioksidan dengan dosis yang tepat, semakin tinggi dosis serbuk daun kayu manis dapat menghambat proses metabolisme dan mempengaruhi kesehatan ikan (Desmiaty, dkk., 2008 dalam Malanggia, dkk., 2012). Sedangkan saponin termasuk senyawa fitokimia yang dapat menghambat peningkatan kadar glukosa darah dengan cara menghambat penyerapan glukosa di usus halus dan menghambat pengkosongan lambung. Dengan melambatnya pengosongan lambung, maka absorpsi makanan akan semakin lama dan mempengaruhi proses penyerapan nutrisi sehingga dapat menurunkan tingkat kesehatan ikan dan menimbulkan kematian (Bruneton, 1999; Matsuda, et al., 1999; Mahendra dan Fauzi, 2005). 


\section{Bobot Mutlak (g)}

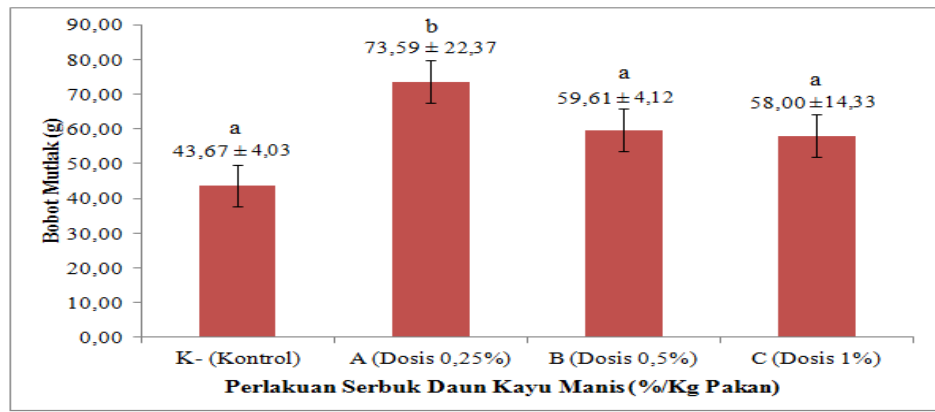

Gambar 2. Bobot mutlak (g) Ikan Nila (Oreochromis niloticus) selama penelitian.

Tabel 5. Analysis of variance (ANOVA) Data Bobot mutlak ikan nila (Oreochromis niloticus) yang diberi pakan dengan penambahan serbuk daun kayu manis selama 30 hari pemeliharaan.

\begin{tabular}{llllll}
\hline SK & Db & JK & KT & F hitung & F5\% \\
\hline Perlakuan & 3 & 3158,019 & 1052,673 & 7,365 & 0,011 \\
Galat & 8 & 1143,404 & 142,926 & & \\
Total & 11 & 4301,423 & & & \\
\hline
\end{tabular}

Hasil uji ANOVA pada pertumbuhan bobot mutlak Ikan Nila (Oreochromis niloticus) menunjukkan bahwa pemberian dosis serbuk daun kayu manis (Cinnamomum burmanii) yang berbeda pada pakan berpengaruh nyata terhadap parameter yang diamati $(\mathrm{p}<0,05)$.

Tabel 6. Uji TukeyBobot Mutlak ikan nila (Oreochromis niloticus) yang diberi pakan dengan penambahan serbuk daun kayu manis selama 30 hari pemeliharaan.

\begin{tabular}{lllll}
\hline Perlakuan & Perlakuan & $\begin{array}{l}\text { Rata-rata } \\
\text { perbedaan }\end{array}$ & Std. Error & Sig \\
\hline PerlakuanK- (Kontrol) & A dosis 0,25\%/kg pakan & $-33,91333^{*}$ & 9,76134 & 0,034 \\
\hline & B dosis 0,5\%/kg pakan & 4,06667 & 9,76134 & 0,974 \\
\hline & C dosis 0,1\%/kg pakan & 5,67000 & 9,76134 & 0,935 \\
\hline Perlakuan A dosis 0,25\%/kg pakan & K- (Kontrol) & $33,91333^{*}$ & 9,76134 & 0,034 \\
\hline & B dosis 0,5\%/kg pakan & $37,98000^{*}$ & 9,76134 & 0,019 \\
\hline & C dosis 0,1\%/kg pakan & $39,58333^{*}$ & 9,76134 & 0,015 \\
\hline Perlakuan B dosis 0,5\%/kg pakan & K- (Kontrol) & $-4,06667$ & 9,76134 & 0,974 \\
\hline & A dosis 0,25\%/kg pakan & $-37,98000^{*}$ & 9,76134 & 0,019 \\
\hline \multicolumn{2}{c}{ C dosis 0,1\%/kg pakan } & 1,60333 & 9,76134 & 0,998 \\
\hline Kerlakuan C dosis 0,1\%/kg pakan & K- (Kontrol) & $-5,67000$ & 9,76134 & 0,935 \\
\hline B dosis 0,5\%/kg pakan & A dosis 0,25\%/kg pakan & $-39,58333^{*}$ & 9,76134 & 0,015 \\
\hline
\end{tabular}

*Perbedaan yang signifikan dengan tingkat kepercayaan $95 \%$ atau $(\mathrm{p}<0,05)$.

Pemberian serbuk daun kayu manis (Cinnamomum burmani) pada perlakuan dalam aktivitas penelitian ini, ikan nila dapat tumbuh lebih baik dari pada kontrol, karena penggunaan bahan alami serbuk daun kayu manis yang merupakan salah satu bahan fitofarmaka yang mengandung sinnamaldehid yang digunakan ikan dalam proses metabolisme sehingga pertumbuhan mutlak pada perlakuan mengalami peningkatan pertumbuhan dibandingkan dengan kontrol tetapi untuk memperoleh pertumbuhan mutlak yang optimal harus dengan dosis tertentu yaitu dengan $0,25 \%$. Fitofarmaka merupakan sediaan bahan alam dari tanaman yang telah 
terbukti keamanan dan kasiatnya secara alamiah dengan uji klinis dan bahan baku serta produk jadinya telah distandarisasikan (Badan POM.RI. 2005).

\section{Laju Pertumbuhan Spesifik (\%/Hari)}

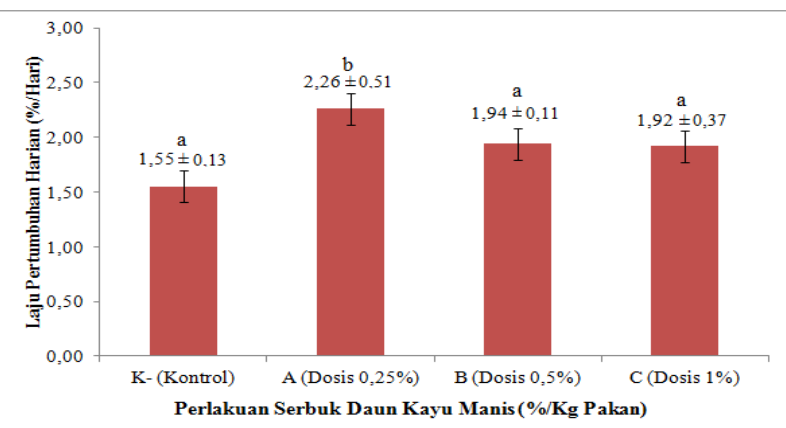

Gambar 3. Laju pertumbuhan spesifik (\%/Hari) Ikan Nila (Oreochromis niloticus) selama penelitian.

Tabel 8. Analysis of variance (ANOVA) Data Laju Pertumbuhan Spesifik ikan nila (Oreochromis niloticus) yang diberi pakan dengan penambahan serbuk daun kayu manis selama 30 hari pemeliharaan.

\begin{tabular}{llllll}
\hline SK & Db & JK & KT & Fhitung & $\mathbf{F 5}_{5} \%$ \\
\hline Perlakuan & 3 & 19,108 & 6,369 & 8,065 & 0,008 \\
Galat & 8 & 6,318 & 0,790 & & \\
Total & 11 & 25,426 & & & \\
\hline
\end{tabular}

Hasil uji ANOVA pada laju pertumbuhan spesifik Ikan Nila (Oreochromis niloticus) menunjukkan bahwa perlakuan dengan pemberian dosis serbuk daun kayu manis (Cinnamomum burmanii) yang berbeda pada pakan berpengaruh nyata terhadap parameter yang di amati $(\mathrm{p}<0,05)$.

Tabel 9. Uji Tukey Laju Pertumbuhan Spesifik ikan nila (Oreochromis niloticus) yang diberi pakan dengan penambahan serbuk daun kayu manis selama 30 hari pemeliharaan.

\begin{tabular}{lllll}
\hline Perlakuan & Perlakuan & $\begin{array}{l}\text { Rata-rata } \\
\text { perbedaan }\end{array}$ & Std. Error & Sig \\
\hline PerlakuanK- & A dosis 0,25\%/kg pakan & $-2,70667^{*}$ & 0,72559 & 0,024 \\
(Kontrol) & B dosis 0,5\%/kg pakan & 0,28000 & 0,72559 & 0,979 \\
& C dosis 0,1\%/kg pakan & 0,30333 & 0,72559 & 0,974 \\
\hline Perlakuan A & K- (Kontrol) & $2,70667^{*}$ & 0,72559 & 0,024 \\
dosis 0,25\%/kg & B dosis 0,5\%/kg pakan & $2,98667^{*}$ & 0,72559 & 0,014 \\
pakan & C dosis 0,1\%/kg pakan & $3,01000^{*}$ & 0,72559 & 0,014 \\
\hline Perlakuan B & K- (Kontrol) & $-0,28000$ & 0,72559 & 0,979 \\
dosis 0,5\%/kg & A dosis 0,25\%/kg pakan & $-2,98667^{*}$ & 0,72559 & 0,014 \\
pakan & C dosis 0,1\%/kg pakan & 0,02333 & 0,72559 & 1,000 \\
\hline Perlakuan C & K- (Kontrol) & $-0,30333$ & 0,72559 & 0,974 \\
dosis 0,1\%/kg & A dosis 0,25\%/kg pakan & $-3,01000^{*}$ & 0,72559 & 0,014 \\
pakan & B dosis 0,5\%/kg pakan & $-0,02333$ & 0,72559 & 1,000 \\
\hline
\end{tabular}

*Perbedaan yang signifikan dengan tingkat kepercayaan $95 \%$ atau $(\mathrm{p}<0,05)$.

Menurut Amri dan Khairuman (2002) pemberian pakan akan memberikan manfaat yang optimal bagi pertumbuhan dan kelangsungan hidup ikan. Pakan akan diproses dalam tubuh ikan dan unsur-unsur nutrient atau gizinya akan diserap untuk dimanfaatkan dalam membangun jaringan dan daging, sehingga pertumbuan ikan akan terjamin. Persentase pada perlakuan penambahan 
serbuk daun kayu manis (Cinnamomum burmanii) pada pakan ikan nila (Oreochromis niloticus) berkisaran 1,55-2,26 \%, serbuk daun kayu manis (Cinnamomum burmani) dapat membantu ikan dalam memanfaatkan protein yang terkandung dalam pakan sehingga dapat memaksimalkan proses metabolisme dan kesehatan ikan dengan dosis tertentu yaitu 0,25\%. Fungsi lain dari pakan adalah untuk membantu mempercepat kematang gonad sehingga proses reproduksi dapat dipercepat (Liviawati dan Afrianto, 2005).Pada ikan patin 8,5 g, penambahan serbuk daun kayu manis pada pakan dapat meningkatkan protein tubuh, retensi protein dan kecernaan protein (Setiawan dkk., 2014).

\section{KESIMPULAN DAN SARAN \\ Kesimpulan}

Dapat di simpulkan dari hasil pelaksanaan penelitian ini:

1. Kelangsungan hidup dengan perlakuan pemberian dosis serbuk daun kayu manis yang berbeda pada pakan pellet terapung F999 pada ikan nila (Oreochromis niloticus) berpengaruh nyata dan didapatkan kelangsungan hidup survival rate terbaik pada perlakuan $\mathrm{A}$ dosis $0,25 \% / \mathrm{kg}$ pakan sebesar $63,3 \%+5,77$.

2. Pertumbuhan dengan perlakuan pemberian dosis yang berbeda pada pakan pellet terapung F999 pada ikan nila (Oreochromis niloticus) berpengaruh nyata dan di dapatkan pertumbuhan mutlak yang terbaik pada perlakuan A dosis $0,25 \% / \mathrm{kg}$ pakan sebesar $73,59 \pm 22,37 \mathrm{~g}$, sedangkan laju pertumbuhan spesifik yang terbaik pada perlakuan A dosis $0,25 \% / \mathrm{kg}$ pakan sebesar 2,26g.

\section{Saran}

Perlakuan dalam penelitian ini untuk apakah pemberian serbuk daun kayu manis dengan dosis yang berbeda pada pakan pellet terapung dengan protein $38 \%$ berpengaruh terhadap pertumbuhan mutlak, laju pertumbuhan spesifik ataupun kelangsungan hidup. Para pembudidaya ikan nila (Oreochromis niloticus) diharapkan dapat menerapkan penambahan serbuk daun kayu manis (Cinnomamum burmanii) dengan dosis terbaik yang didapatkan dengan dosis perlakuan A yaitu dosis $0,25 \% / \mathrm{kg}$ pakan untuk memperoleh hasil yang maxsimal.

Persiapan air minimal 1 minggu sebelum kedatangan bibit ikan nila dalam tendon sehingga dapat dipakai kapan pun ketika benih ikan nila (Oreochromis niloticus) sudah siap untuk di masukkan di aquarium atau dalam proses pergantian air akuarium yang dilakukan setiap 10 hari selama masa penelitian.

\section{DAFTAR PUSTAKA}

Suriawidjaja, E. H. 2005. Akuakulture Berbasis Tropic Level: Revitalisasi untuk Ketahanan Pangan, Daya Saing Ekspor dan Kelestarian Lingkungan dalam 60 Tahun Perikanan Indonesia. Masyarakat Perikanan Indonesia: 171 -178

Anonim. 2006. The Indonesia Aquaculture Statistics 2004. Direktorat Jendral Perikanan Budidaya, Jakarta.

Hamidah S, Burhanudin V, Istikowati WT. 2009. Kajian sifat-sifat dasar kayu manis sebagai pertimbangan pemanfaatan limbah pemanenan kulit kayu manis (Cinnamomum burmanii, Blume). Jurnal Hutan Tropis Borneo, 10(26): 210-223

Setiawati, J. A., Tarsim., Y. T. Adiputra dan S. Hudaidah. 2014. Pengaruh Penambahan Probiotik Pada Pakan dengan Dosis Berbeda Terhadap Pertumbuhan, Kelulushidupan, Efisiensi Pakan dan Retensi Protein Ikan Patin (Pangasius Hypophthalamus). E-Jurnal Rekayasa dan Teknologi Budidaya Perairan, I (2): 151-162. 
$\underline{\text { Jurnal Perikanan Pantura (JPP) Volume 1, Nomor 1, Maret } 2018}$

Amri K, Khairuman. 2003. Budidaya Ikan Nila Secara Intensif. Jakarta: Agromedia Pustaka.

Gunawan D. dan S. Mulyani. 2004. IlmuObatAlam (Farmakognosi) Jilid 1. PenebarSwadaya. Jakarta.

Wang R, Wang R, Yang B. 2009. Extraction of their volatile compound compositions, Innovative Food Science and Emerging Technologies. 10 : 289-292

BPOM RI. (2005). Peraturan Kepala Badan Pengawasan Obat dan Makanan Republik Indonesia Nomor HK 00.05.41.1384 tentang Kriteria dan Tata Laksana Pendaftaran Obat Tradisional 